\title{
Den private religion: \\ Fortolkninger af muslimske børns religiøse tilhørsforhold i en dansk folkeskole
}

\author{
Marianne Holm Pedersen
}

\begin{abstract}
While the teaching of religion in the Danish folkeskole is a widely debated issue, there is little knowledge about how parents of Muslim background relate to the role of religion in the children's daily school life. This article explores the meanings that teachers and parents at a school in the Danish province attribute to Muslim children's religious backgrounds. Based on interviews with school leadership, teachers, parents and children, it particularly examines how they interpret the course 'knowledge of Christianity' and how they view the division of responsibility for teaching children about religion. It argues that while both parents and teachers understand religious belonging as a private matter that does not concern the school, they have different understandings of what this means and what it should imply for the children's participation in school activities. The article further argues that the so-called encounter between 'Muslim practices' and 'Danish values' rather constitutes yet another example of negotiations that have always taken place in modern Danish society between the institutions of family and school.
\end{abstract}

I begyndelsen af 2000'erne kom Ålholm Skole i Valby i centrum for både offentlig og politisk debat. På grund af skolens etnisk mangfoldige elevgruppe havde skolebestyrelsen besluttet at omdøbe faget kristendomskundskab til 'religion' og ændre læseplanen, så den i højere grad tog højde for elevernes forskellige religiøse baggrund. Læseplanen blev positivt modtaget af Københavns Kommune, men i 2004 kendte Undervisningsministeriet den ulovlig, blandt andet fordi det ikke fremgik tydeligt nok af læseplanen, at fagets centrale kundskabsområde er den danske folkekirkes evangelisk-lutherske kristendom (Rasmussen 2004).

Sagen om Ålholm Skole er blot ét eksempel på den megen debat, der jævnligt omgærder faget kristendomskundskab og dets betydning $\mathrm{i}$ skoler, hvor en del af eleverne har anden religiøs, typisk muslimsk, baggrund. Diskussionen om, hvorvidt fagets navn bør ændres til 'religion', står centralt i denne debat. Da jeg i 2011 udførte feltarbejde blandt muslimske familier $\mathrm{i}$ en vestsjællandsk provinsby, havde jeg imidlertid en samtale med Said ${ }^{1}$, far til tre børn, der alle er fritaget fra kristendom. Han sagde, at selv hvis faget kristendomskundskab blev omdøbt til religion, og børnene lærte mere om islam, ville han ikke lade dem deltage. Said fortsatte: "Det her, det synes jeg, det er en privat del af livet, for et barn og for os, som vi gerne selv vil give". Til mit uddybende spørgsmål, om det ikke ville gøre nogen forskel, at faget hed religion,

\footnotetext{
${ }^{1}$ Af hensyn til de deltagende familiers anonymitet er alle navne pseudonymer, og enkelte personlige oplysninger er ændret. Skolens navn er ligeledes ændret.
} 
svarede han: "Ja, det betyder ikke noget. Det betyder slet ikke noget. For religion det vil jeg gerne selv give. Og jeg giver dem alt. Og de spørger om alt". I modsætning til en udbredt antagelse om, at et nyt navn og andet indhold vil gøre religionsundervisningen acceptabel for en bredere gruppe forældre, understreger Said her, at han ikke synes, skolen skal undervise børn om religion overhovedet. Saids udsagn peger på, at muslimske børns fritagelse fra kristendomskundskab måske handler om andet og mere, end at de ikke skal lære om andre religioner.

Denne artikel undersøger, hvilken betydning forståelser af religion og religiøst tilhørsforhold får for muslimske familiers møde med en dansk folkeskole på Vestsjælland. På baggrund af interviews med lærere, forældre og børn belyser artiklen forskellige perspektiver på, hvilken rolle familiernes religiøse baggrund spiller for børnenes skolegang, herunder hvorfor muslimske børn bør eller ikke bør deltage i faget kristendomskundskab. Der findes mange politiske holdninger til disse spørgsmål, men der eksisterer meget lidt viden om, hvordan de bliver forhandlet i praksis. Ikke mindst mangler der viden om, hvordan muslimske familier forholder sig til de aspekter af deres børns skolegang, der relaterer sig til religiøse aspekter. Artiklen viser, at mens både lærere og forældre forstår religiøst tilhørsforhold som noget privat, der ikke vedrører skolen, har de forskellige forståelser af, hvad dette indebærer, og deres opfattelser har således forskellige implikationer for praksis. Artiklens konklusioner peger på, at det beskrevne møde mellem 'muslimer' og 'dansk praksis' i lige så høj grad kan forstås som et klassisk eksempel på et møde mellem de to samfundsinstitutioner familie og skole.

Artiklen er baseret på data fra et feltarbejde i en vestsjællandsk provinsby. ${ }^{2}$ Med udgangspunkt i en lokal folkeskole interviewede jeg medlemmerne i 17 familier med børn i 2. og 4. klasse. ${ }^{3}$ Formålet var at undersøge, hvordan forældrene lærer deres børn om religion, hvordan børnene tilegner sig religiøs praksis og identitet, samt på hvilke måder de forskellige familiemedlemmer oplever, at deres religiøse baggrund spiller en rolle for børnenes hverdag i folkeskolen. I tillæg til interviews udførte jeg i nogle tilfælde deltagerobservation i hjemmene, ved privat religionsundervisning og i skolen eller til skolearrangementer. Projektets hovedfokus var på familier med muslimsk baggrund, men med henblik på sammenligning interviewede jeg også forældre og børn i enkelte familier med anden minoritetsreligiøs baggrund. På baggrund af den forholdsvis begrænsede mængde data er det ikke artiklens formål at komme med repræsentative konklusioner, men snarere at pege på nogle

\footnotetext{
2 Projektet fandt sted som del af det kollektive forskningsprojekt "Islam, muslimer og danske skoler" (2009-2013), som blev finansieret af Det Frie Forskningsråd og Aarhus Universitets Forskningsfond. Jeg takker ledelsen og lærerne på 'Dannevangskolen' for deres villighed til at hjælpe mig og bruge tid på mig. Jeg takker også de forældre og børn, der lukkede mig ind i deres hjem og beredvilligt svarede på mine spørgsmål. Endelig takker jeg Laura Gilliam, Sidsel Vive Jensen, Tina Gudrun Jensen, Mikaela von Freiesleben og Kristina Grünenberg for deres konstruktive kommentarer til tidligere udkast af denne artikel og Ditte Bentzon Goldschmidt for korrekturlæsning af den endelige version.

${ }^{3}$ I seks af familierne interviewede jeg begge forældre, $i$ de resterende 11 interviewede jeg den ene, typisk moderen. I næsten alle familierne har jeg enten talt med eller interviewet et eller flere af børnene.
} 
tematikker, som det er værd at tage højde for i diskussionen om muslimske elevers hverdag i folkeskolen.

\section{Forskellige opfattelser af privat og offentlig}

Som adskillige forskere har påpeget, er folkeskolens generelle projekt ikke blot at uddanne eleverne, men også at skabe og danne borgere i den danske nationalstat (fx Gilliam 2009). I den forbindelse har skolen en integrerende funktion i samfundet. Denne funktion er ikke blot opstået med den indvandring, der har fundet sted siden 1960'erne. Helt fra den almene skolegang opstod i begyndelsen af 1800-tallet, har den danske folkeskole integreret borgerne, $\mathrm{fx}$ identitetsmæssigt ved at prioritere nationen som en vigtig ramme for samfundet, sprogligt ved at legitimere en bestemt sprogform som det korrekte dansk (i modsætning til lokale dialekter), og kulturelt ved at udbrede specifikke værdier og kundskaber, der nok har ændret sig over tid, men som alligevel forstås som særligt danske (Gitz-Johansen 2006: 31-45). Ved at etablere en adskilt kulturel verden skal skolen tage børnene ud af deres sociale sammenhæng og sætte dem lige inden for et nyt fællesskab (Gilliam 2009: 56). Som et led i institutionaliseringen af uddannelse og dannelse $\mathrm{i}$ folkeskolen blev ansvaret for en del af børnenes opdragelse altså flyttet fra én samfundsinstitution til en anden, nemlig fra familien til skolen. I skolens tidlige år blev dette af mange betragtet som problematisk, da børnene ofte indgik i husholdets arbejdsstyrke, og det var først omkring år 1900 (altså 86 år efter indførelsen af den almene undervisningspligt), at de fleste børn i Danmark fik syv års skolegang (Gilliam og Gulløv 2012: 4243). Som Gilliam og Gulløv skriver, fungerer skolens kollektive opdragelsesprojekt ved at adskille børn fra deres hjemmemiljø, og faktisk "ligger der $i$ selve ideen om at etablere opdragelses- og læringsinstitutioner for børn en implicit mistillid til, at forældrene kan varetage deres børns opdragelse tilstrækkelig kompetent" (ibid. 44). Ansvarsfordelingen mellem skole og familie har altså altid været til forhandling. Grænserne mellem de to institutioner flytter sig dog over tid. Hvor forældrene i 1960'erne primært skulle støtte uddannelsesprojektet ved at give lektiehjælp og understøtte lærerens autoritet, er forældre i dag også ansvarlige for at udvikle børnenes sociale kompetencer og støtte op om deres deltagelse i sociale arrangementer, såsom legeaftaler, klassefester eller fødselsdage (Gilliam og Gulløv 2012: 51, 53-54). Samtidig både inddrager og civiliserer velfærdsstatens børneinstitutioner (herunder også vuggestuer og børnehaver) i stigende grad familien (se fx Gulløv 2011). Det synes derfor værd at se nærmere på relationen mellem disse grundlæggende samfundsinstitutioner.

Et af de fag, hvor forholdet mellem familie og skole kan komme i spil, er kristendomskundskab. Mens fag som dansk eller matematik af de fleste forældre betragtes som nødvendige, for at børnene kan lære bestemte færdigheder, udgør kristendomskundskab et af de fag, hvor skolens ønske om at forme børnene til et bestemt kulturelt fællesskab mere eksplicit kommer til udtryk. Selvom skolen generelt betragtes som en sekulær institution, har kristendommen, og senere faget kristendomskundskab, altid spillet en særlig rolle i folkeskolens historie. Da den almene skole blev grundlagt i 1814, var formålet blandt andet "at danne børnene til gode og retskafne mennesker i overensstemmelse med 
den evangelisk-kristelige lære" (Gilliam og Gulløv 2012: 42). Selvom der skete justeringer hen ad vejen, vedblev den forkyndende undervisning $i$ kristendom helt frem til 1975 med at være et vigtigt formål i folkeskolen. Herefter vedtog man med den nye folkeskolelov, at faget kristendomskundskab skulle have den danske folkekirkes evangelisklutherske kristendom som sit centrale kundskabsområde. Mens skolen således ikke længere skulle forkynde kirkens budskab, eksisterer der fortsat ikke en lov, der faktisk forbyder undervisningen i kristendomskundskab at være forkyndende (Sedgwick 2014). Af lovens bemærkninger synes det $\operatorname{dog}$ at fremgå, at undervisningen ikke skal indeholde bevidst religiøs påvirkning af eleverne (Jepsen 2012: 32). Ved en ændring af folkeskoleloven i 1993 blev det specificeret, at mens undervisningen fra 1. - 6. klasse hovedsageligt skal fokusere på den evangelisk-lutheranske kristendom, skal eleverne fra 7 . klasse introduceres til andre religioner, herunder islam. Det er dog op til den enkelte lærer at tilrettelægge undervisningen, og flere lærebøger inddrager fx referencer til andre religioner allerede i de mindre klasser (se Sedgwick 2014). Med andre ord kan det variere meget fra skole til skole og klasse til klasse, hvordan der i praksis undervises i faget (se fx Buchardt 2008, Jenkins 2011: 237ff, Jepsen 2012). Fælles er, at faget undervises én time ugentligt fra 1. til 9. klasse, og i 2006 blev det til et prøvefag med en afgangseksamen. Forældre, der ikke ønsker, at deres børn skal modtage undervisning $i$ kristendom, har ret til at barnet fritages, hvis "forældremyndighedens indehaver skriftligt over for skolens leder erklærer selv at ville sørge for barnets religionsundervisning" (Folkeskoleloven \6, stk. 2).

Set $i$ en bredere sammenhæng kan kristendomskundskab i en dansk kontekst anskues som en del af den "civile enkulturation", der foregår i skolen (jf. Schiffauer et al. 2004). Som antropologen Gerd Baumann (2004) påpeger, videregiver skoler i dag en form for civil kultur til deres elever. I et samfund med forskellige etniske befolkningsgrupper er det ikke nødvendigvis et særligt nationalt indhold, der skal læres, men snarere en form for civil kompetence, som eleverne skal tilegne sig, dvs. 'hvordan man gør', når man skal fungere som borger i fx Danmark. Her tænkes ikke på levevis, men på de kompetencer som skal til, for at man kan fungere i civilsamfundet. Som han skriver: "It is about the methods of arguing one's point rather than the content of any one argument" (Baumann 2004: 4, min kursivering). Overføres dette argument på faget kristendomskundskab, kunne man hævde, at selvom faget ikke har til formål at forkynde kristendommen til eleverne, videregives der måske alligevel implicit en bestemt måde at forholde sig til religion på, eller en bestemt måde at forstå religionens plads i det offentlige rum på, som er udbredt i det danske samfund. En lignende observation er gjort i Sverige, hvor den obligatoriske religionsundervisning i skolen har skiftet navn fra kristendomskundskab til religionskundskab for at understrege fagets ikke-forkyndende karakter. Her har religiøse grupper anklaget faget for snarere at uddanne børnene til ateisme eller sekularisme end at lære dem om religion, mens andre har påpeget, hvordan den såkaldt neutrale tilgang til religion er dybt præget af luthersk protestantisme (se Berglund 2013: 173, 181). 
Måderne, hvorpå muslimske elever i folkeskolen diskuteres og håndteres, kan dermed ikke adskilles fra den plads, religion generelt har i det øvrige samfund. Ambivalensen mellem en sekulær institution som skolen og kristendomsfagets rolle går igen $\mathrm{i}$ ambivalensen mellem et sekulariseret samfund og kristendommens dominerende rolle i Danmark. Ifølge den danske grundlov er der religionsfrihed, men ikke religionslighed i Danmark (Rubow 2011: 96). Danmark har en offentligt støttet folkekirke, og både samfundet og dets institutioner er "gennemsyret" af luthersk kristendom (Nielsen 2011: 3). Samtidig eksisterer der en stærk diskurs om adskillelse af religion og politik og en generel sekularisering af samfundet. I forståelsen af det danske samfund som sekulært bliver religion i et vist omfang til et personligt spørgsmål, der henvises til den private sfære (Rubow 2011: 100). Privatsfæren forstås her som et særligt, socialt rum, der er afgrænset fra den offentlige sfære, og hvor individer og familier kan udøve de religiøse overbevisninger, de i stigende grad selv vælger. En sådan uproblematisk opsplitning mellem det offentlige og det private er imidlertid ikke analytisk holdbar, $\mathrm{fx}$ fordi individers private, religiøse overbevisninger ofte kan påvirke deres opførsel $\mathrm{i}$ det offentlige rum, eller fordi institutionaliseret, offentlig religion griber ind i privatsfæren (Beckford 2003: 86). Ifølge Dobbelaere (1999: 233) er offentlig/privat et ideologisk begrebspar, der på den ene side bruges til at legitimere religionens uddrivelse af sekulære institutioner ('religion er en privatsag og derfor ikke relevant her'), og på den anden side kan bruges af individuelle aktører til at forsvare sig mod institutioners indblanding i deres religiøse aktiviteter ('dette er vores privatliv, bland jer udenom'). Hvordan religion defineres, er altså del af en forhandling om dens plads i samfundet, og om hvem der har retten til at bestemme dens indhold. Som sociologen James Beckford påpeger, bliver den analytiske udfordring dermed at undersøge "de processer, hvor definitionen af det private og det offentlige konstrueres, udfordres og konstant genforhandles på forskellige steder og under forskellige omstændigheder" (2003: 63, min oversættelse).

Som det vil fremgå af den følgende analyse, kommer opfattelser af privat religion i den konkrete skolesammenhæng i spil, enten når skolens praksis opfattes som gribende ind $\mathrm{i}$ familiens sfære, eller når familiens fortolkning af religiøs praksis bliver aktualiseret i sociale sammenhænge $i$ skolen. Her bliver det klart, at mens både lærere og forældre henviser til den udbredte opfattelse af, at religiøst tilhørsforhold er privat, forstår de ikke nødvendigvis religion på samme måde, og derfor er de heller ikke altid enige om, hvad det private indebærer. Denne forhandling af grænserne mellem skole og familie eller mellem privat og offentlig religion bliver ikke mindst aktualiseret i faget kristendomskundskab.

\section{Baggrund om Dannevangskolen}

Som vist ovenfor, kan nationale rammer have stor betydning for religionens plads i den danske folkeskole, men samtidig vil der være stor variation på tværs af forskellige skoler, der blandt andet er påvirket af lokale forhold, ledelsens ideologi og elevgruppen (se fx Jensen 2013). I det følgende vil jeg præsentere nogle af overvejelserne omkring 
muslimske elever, islam og kristendom på den skole, jeg var tilknyttet, og som jeg her har valgt at kalde Dannevangskolen.

Dannevangskolen er en middelstor folkeskole $i$ en vestsjællandsk provinsby. Skolens distrikt dækker både villaveje, rækkehuskvarterer og boligblokke, og skolens elevgruppe er således potentielt blandet. Ifølge ledelsen kommer en overvægt af eleverne dog fra ressourcesvage familier med etnisk dansk baggrund. Den sociale belastning skyldes fx arbejdsløshed, psykisk sygdom og misbrug. Skolen havde i mange år ca. 10-12\% elever med anden etnisk baggrund, men pga. en omlægning af skoledistrikterne steg dette tal inden for et par år til ca. $25 \%$. I samme periode oplevede skolen, at ressourcestærke forældre med etnisk dansk baggrund i stigende grad sendte deres børn til andre skoler.

Dannevangskolens største udfordring er således ikke at håndtere elever med anden etnisk baggrund, men snarere at håndtere sociale problemer blandt elevpopulationen generelt. Ikke desto mindre betød det faktum, at skolen forholdsvis pludseligt havde en større gruppe elever med muslimsk baggrund, at skolen i stigende grad måtte forholde sig til temaer relateret til islam. Ifølge skolelederen er det diskussioner om fritagelse fra fælles badning efter idræt og fritagelse fra kristendomskundskab, der fylder mest i hverdagen. I det første tilfælde har skoleledelsen valgt at forholde sig forholdsvis pragmatisk, og børn med muslimsk baggrund kan efter forespørgsel fra forældrene få lov til at gå i bad før de andre elever. Ifølge skolelederen er tiden løbet fra de kollektive badeforhold, skolen pt. er indrettet med, og det er ikke ualmindeligt, at også ikke-muslimske teenagere er utilpasse ved at skulle bade sammen med andre. Fra skolelederens perspektiv bruger de unge muslimer her deres religion til at opnå et formål (at undgå at vise sig nøgne foran andre), der ikke er specifikt religiøst (jf. Jensen og Kühle 2013: 2).

I forhold til fritagelse fra kristendomskundskab har skolen valgt en mere aktiv politik. Da fritagelse ifølge ministeriel praksis normalt kun kan ske fra begyndelsen af et skoleår (https://www.retsinformation.dk /Forms/R0710.aspx?id=24561), har man indført en regel om, at en anmodning om fritagelse fra kristendomskundskab skal afleveres inden sommerferien. Ellers vil barnet først kunne fritages fra det efterfølgende skoleår. Da mange forældre ikke får søgt $\mathrm{i}$ rette tid, betyder det reelt, at børnene ikke fritages, og antallet af fritagne børn er dermed faldet fra ca. 60 til under 10 muslimske elever pr. år. I enkelte tilfælde kan det ifølge skolelederen være nødvendigt at finde en løsning $\mathrm{i}$ løbet af skoleåret, men han påpegede, at de fleste forældre respekterede reglerne, når de fandt ud af, at der var en fast politik på området. Skoleledelsen havde valgt denne politik, da de betragter faget kristendomskundskab som grundlæggende for forståelsen af det danske samfunds kulturelle basis. De elever, som ikke har kristendomskundskab, risikerer altså at mangle basal viden, der er nødvendig for en ordentlig inklusion i samfundet.

\section{Lærernes perspektiver på kristendomskundskab og religionens rolle i skolen}

Selvom det er ledelsen, der laver skolens politik, er det lærerne, der skal udmønte den, og det er også lærerne, som forældrene først og fremmest møder som repræsentanter for skolen. De fire lærere, som jeg 
interviewede i forbindelse med projektet, betragtede alle kristendomskundskab som et vigtigt fag $\mathrm{i}$ skolen. Den ene lærer understregede betydningen af det kristne som grundlag $\mathrm{i}$ det danske samfund, mens en anden lærer snarere fokuserede på, hvordan læring om forskellige religioner kan hjælpe elever med mere generelt at forstå verden og de konflikter, der foregår i den. Blandt lærerne i de yngre klasser blev faget også set som et vigtigt element i undervisningen, ikke nødvendigvis pga. den specifikke viden om kristendom, men snarere pga. fagets tilknytning til bredere etiske og moralske spørgsmål. Kristendomskundskab blev således ikke set som et enkeltstående fag, men som tilknyttet temaer, eleverne også ville støde på og diskutere i andre fag. I den forstand påpegede læreren Katja fagets betydning for den sproglige og begrebsmæssige udvikling blandt tosprogede børn:

Katja: Jeg lægger vægt på at forklare forældrene, at det handler rigtig meget om, at [børnene] får en begrebsverden, der bliver meget større. Fordi de får ord for en masse begreber, fordi kristendomsundervisningen ikke handler om kristendom i særlig høj grad, og det handler slet ikke om at være kristen i hvert fald på den måde, men lige så meget om sådan det almindelige...

Anden lærer: Tilværelsessspørgsmål...

Katja: Tilværelsesspørgsmål med liv og død og had og kærlighed osv. Og mange tosprogede børn mangler danske ord for begreber og forståelsen for de begreber, og derfor er det et super vigtigt fag.

Katja og hendes kollega anså altså de temaer, som bliver behandlet i kristendomskundskab, som et vigtigt element i børnenes dannelse. Mens lærerne alle understøttede fagets fortsatte eksistens, var det meget vigtigt for dem, at kristendomskundskab ikke handler om at forkynde det kristne budskab, men om at formidle viden om religioner generelt. For lærerne Jette og Mie ville en naturlig konsekvens af dette være, at kristendomskundskab burde skifte navn til 'religion', en diskussion, der som nævnt dukker op i den offentlige debat med jævne mellemrum. Ifølge dem ville det være en mere korrekt betegnelse for fagets indhold, der heller ikke ville bringe forældre i tvivl om, hvad fagets formål var. Mie undlod sågar at skrive kristendomskundskab på sin kursusbeskrivelse, men skrev i stedet religion:

Mie: Jeg kan næsten ikke få det over min mund, altså.[...] Jeg synes ikke, man kan kalde det kristendom, det er et klart signal om, at det jo er dobbeltmoralsk. At sige til de muslimske forældre, jamen det er ikke forkyndende, men det hedder kristendom, altså det hænger ikke helt sammen, vel.

Mens kristendomskundskab er det fag, hvor religiøse forskelle tydeligst kommer i spil, betyder det ikke, at religionens rolle i skolen er begrænset til undervisningen. Her vil jeg blot pege på to elementer, hvor lærerne faktisk havde forskellige holdninger til, hvordan de skulle håndteres. Den ene problematik relaterer sig til fejringen af kristne traditioner i skolen. Som mange andre institutioner $i$ det danske samfund fejrede 
Dannevangskolen danske - og kristne - traditioner ved $\mathrm{fx}$ at markere julens komme ved en klippe/klistredag i klasserne og ved at afslutte kalenderåret med deltagelse i en julegudstjeneste. Hvis skolen betragtes som et sekulært rum, hvor folks egen religiøse praksis ikke hører til, kan de kristne traditioners plads i skolen siges at være ambivalent. Lærerne var da heller ikke helt enige om, hvilken plads kristne aktiviteter, såsom en julegudstjeneste, skulle have i skolen. Mens Jette betegnede dette som en hyggelig tradition, der varsler julens ankomst, anså Mie det at gå i kirke som en praksis, der tilhører privatlivet. For Jette var det nok, at de muslimske elever blev tilbudt en alternativ hyggestund på skolen, hvorimod Mie fandt, at det skabte unødige skel i klassen, når tre elever sad alene tilbage på et tidspunkt, hvor hele klassen kunne have været sammen. Mies modstand hang således både sammen med en generel holdning til adskillelse af religion og skole og en kritik af den konkrete udmøntning, hvor visse elever $\mathrm{i}$ hendes øjne blev ekskluderet fra fællesskabet. Mens Mie på den måde udtrykker en mere sekularistisk tilgang til religionens plads i skolen, synes Jette snarere at repræsentere en mere traditionel holdning, hvor kristendommen anses som en del af dansk kultur, og hvor kirkebesøget snarere betragtes som en skoletradition end en decideret religiøs tradition (jf. Rubow 2001: 97ff, Gilliam dette nummer).

Et andet spørgsmål var, hvorledes lærerne forholdt sig til en elevs egen religiøse baggrund, og de traditioner der var forbundet med den. Jette, der underviser på mellemtrinnet, spurgte fx tit til børnenes fejring af eid i familien: hvad laver I egentlig, hvad fik I at spise, og hvordan siger man glædelig eid, var nogle af de spørgsmål, hun kunne finde på at stille. I hendes øjne var det en måde at vise interesse for sine elever på, som børnene også satte pris på. Katja havde en anden tilgang og sagde: "Jeg kunne aldrig finde på at spørge en elev direkte, altså med deres egen private tro". Da Katja tidligere havde fortalt mig, at hun godt kunne finde på at bede muslimske elever om at forklare ramadanen for resten af klassen, spurgte jeg ind til hendes holdning:

Marianne: Når I nu siger, at de forklarer ramadanen, så snakker I vel også om deres egen tro på et eller andet niveau?

Katja: Jo, men det er alligevel, hvad islam i det store billede står for $\mathrm{i}$ forhold til ramadanen, hvorfor holder man ramadan i islam. Det er ikke "hvorfor holder du ramadan". Det tror jeg er vigtigt. Netop også for, at forældrene ikke får den opfattelse, at vi går ind og prøver at pille ved deres tro, fordi det skal vi ikke. Det er deres private sag. $\varnothing \mathrm{h}$, for der har jeg i alt fald nogle forældre, der er meget bekymret for, om vi giver dem et forkert billede af deres egen tro. Og derfor er det super super vigtigt at vi holder de store linjer og kun snakker om, hvad siger islam egentligt. Og ikke alt om, hvordan vi nu fortolker det $\mathrm{i}$ det der hjem, i det der hjem og $\mathrm{i}$ det der hjem, for det gør de på deres egen måde, lige som enhver kristen tolker på deres egen måde. Og det må vi ikke pille ved, det er ikke vores job.

Det er tydeligt, at Katja her oplever et klart skel mellem skolens almene tilgang til religion og familiernes private religion. Hun prøver at undgå at 
blande sig i privatsfæren, men på samme tidspunkt kommer hun til at antage, at der findes en korrekt tolkning af, hvad islam er, som kan adskilles fra familiernes praksis. Selvom det at faste er en af de fem søjler $\mathrm{i}$ islam, findes der jo faktisk mange forskellige forståelser af, hvorfor man gør det. Samtidig kommer Katja indirekte til at gøre de muslimske børn til religiøse mennesker. I modsætning hertil var læreren Mie, som gjorde det til en dyd netop ikke at bede muslimske elever om at svare for islam, men blot spurgte alle klassens elever om, hvorfor man fejrer ramadan. Hvorvidt de muslimske elever så ønskede at svare, var op til dem selv.

Ovenstående eksempler viser, at der blandt ledelse og lærere eksisterer forskellige holdninger til, hvilken rolle religion skal eller ikke skal have i skolen. Dette gælder både i forhold til majoritetssamfundets religion og elevernes muslimske baggrund. Fra skolens perspektiv er undervisning i kristendomskundskab en del af at (ud)danne eleverne og gøre dem til borgere i den danske nationalstat, men det indebærer ikke, at de skal blive kristne. Det er snarere en del af den civile enkulturation (jf. Baumann 2004). Adspurgt om ansvarsfordelingen mellem skole og forældre, påpegede alle fire lærere, at skolen har ansvaret for at undervise i forhold til læringsmålene (de såkaldte Fælles Mål) og introducere eleverne til religioner generelt, tolerance over for anderledes tænkende, begrebsspørgsmål og refleksioner, men det kan aldrig være skolens ansvar at forholde sig til den enkeltes tro eller fortolkning af religion. Dette blev betragtet som privat og den enkelte families ansvar.

I den resterende del af artiklen vil jeg se nærmere på, hvilken betydning forældrene i mit projekt tillagde børnenes religiøse baggrund i religionsundervisningen og i skolen generelt. Det vil blive tydeligt, at lærernes opfattelse af et skel mellem religioner generelt og hvad der er privat, ikke er helt nemt at opretholde i praksis, blandt andet fordi 'den private religion' kan fortolkes på forskellige måder.

\section{Forældrenes perspektiver på ansvaret for læring}

De muslimske familier, der deltog i projektet, kommer fra forskellige etniske, sociale og religiøse baggrunde. Det er derfor ikke overraskende, at der var variation i familiernes måde at praktisere islam på, ligesom det var forskelligt, hvor meget religionen fyldte i familiernes hverdag. Disse forskelle påvirkede også forældrenes holdninger til deres børns deltagelse i skolens forskellige aktiviteter. I forhold til de to temaer, som skolelederen nævnte, var der dog forholdsvis stor overensstemmelse. Alle, undtagen de to familier, der ikke praktiserede islam i hverdagen, ønskede, at deres børn gik i bad før de andre elever eller badede med underbukser, når de havde haft idræt. Omvendt havde alle, undtagen fire familier, valgt, at deres børn skulle deltage i kristendomskundskab, selvom det skete med meget forskellige begrundelser. For to af disse familier var islam (eller kristendom) ikke vigtigt nok til, at de forholdt sig specielt til faget kristendomskundskab. Andre forældre havde en mere eksplicit holdning til, at deres børn ville have godt af at lære om andre religioner, selvom de selv levede som muslimer. Forældre og børn var ikke altid enige om dette punkt, da nogle børn faktisk gerne ville fritages, mens deres forældre fastholdt, at de skulle deltage. Endelig var der et par familier, der egentlig helst ville have deres børn fritaget, men som lod dem deltage $\mathrm{i}$ undervisningen, enten fordi de var bange for, at de ellers 
ikke ville få deres eksamen, eller fordi de troede, at fritagelse ikke længere var en mulighed. Der var således en vis uklarhed om reglerne.

En del forældre betragtede deres religion som en privatsag, dvs. som noget, der vedrørte dem og deres familier, men ikke samfundet generelt. Med andre ord benyttede de sig af det samme skel mellem offentlig og privat religion, som er udbredt $\mathrm{i}$ det danske samfund. Blandt de fire familier, der ønskede deres børn fritaget, ville to familier kun have dem fritaget i de små klasser, mens to ville have dem fritaget hele vejen igennem folkeskolen. Den primære begrundelse for, at børnene skulle fritages, var, at deres viden om islam og kristendom skulle grundlægges $i$ familien. I alle fire familier gik forældrene meget op i at lære børnene om det at være muslim. Islamisk praksis var på mange måder inkorporeret $\mathrm{i}$ hverdagslivet: Forældrene bad dagligt, man brugte islamiske udtryk, når man talte, og hjemmet var indrettet med islamiske objekter, såsom religiøse bøger i reolen eller et bedetæppe klar i hjørnet samt billeder af kaba'en eller korancitater på væggen. Ifølge forældrenes fortællinger indgik børnene $i$ det hele taget $i$ et praksisfællesskab, hvor de i større og større grad blev inddraget i den religiøse praksis, jo ældre de blev. Som små lærte børnene om det at være muslim ved at observere og imitere deres forældre, som fx når små børn efterligner deres forældres bevægelser i bønnen. I familierne blev ramadanfasten overholdt, der blev fortalt narrativer om profeterne og andre religiøse personer, og i det hele taget blev religiøs fortolkning diskuteret med jævne mellemrum. Nogle af børnene gik desuden til undervisning $\mathrm{i}$ islam, enten i moskeen eller privat. ${ }^{4}$ Set i denne sammenhæng af, hvordan børnene tilegner sig islam og det at være muslim i hjemmet, kan man argumentere, at undervisningen i skolen forstyrrer den læringsproces, som skulle finde sted i hjemmet. Ansvaret for at lære børnene om religion - islam såvel som andre religioner - var forældrenes. Citatet fra Said i begyndelsen af artiklen er et eksempel på dette. Forældre er her enige med lærerne om, at ens egen religion er en privatsag, men de fortolker det bredere, end lærerne gør. Mens lærerne i ovenstående citater syntes at betragte det private mere specifikt som religiøs tro og praksis $i$ bjemmet, betragter forældrene børnenes religiøse dannelse som noget, der rækker ind i hele børnenes hverdag. De har dermed et andet syn på, hvem der har ansvaret for at lære børn om religion i det hele taget, og de ser børnenes oplæring som familiens ansvar. I øvrigt var det ikke kun muslimske forældre, der valgte at få deres børn fritaget. En mor af anden religiøs observans fik sin datter fritaget på datterens tidligere skole, da hun syntes, at læreren talte dårligt om andre religioner end kristendom. Da datteren flyttede til Dannevangskolen, valgte hun at opretholde denne fritagelse. Ligeledes overvejede en kristen mor spøgefuldt i løbet af vores samtale, om hun mon ville kunne få sine børn fritaget for den del af undervisningen, der omhandlede de ikke-kristne religioner. Ligesom nogle af lærerne opfattede kristendomskundskab som en måde at diskutere etik og moral med børnene på, blev faget for nogle religiøse familier altså led i en række overvejelser over, hvordan børnenes verdenssyn skulle formes; overvejelser, der ligeledes blev spejlet i

${ }^{4}$ For yderligere diskussion af religiøs socialisering i familierne, se Pedersen 2014. 
forbehold vedr. seksualundervisning (for de muslimske familiers vedkommende) og undervisning om evolutionslæren (for den kristne families vedkommende). Begge institutioner - familie og skole - ønsker altså at præge og opdrage børnene på en måde, der rækker ind i den anden institutions sfære. Dette er et eksempel på et spændingsforhold mellem familien og skolen, der som tidligere nævnt faktisk går langt tilbage $\mathrm{i}$ historien. Det synes derfor relevant at anlægge et bredere perspektiv end blot 'indvandreres og danskeres forskellige kulturer', når man diskuterer de eventuelle uenigheder, der eksisterer mellem skole og familie.

\section{Forældrenes fortolkninger af kristendomskundskab}

Mens forældrenes ønske om fritagelse til dels handlede om den generelle ansvarsfordeling for læring, var det også relateret til en uenighed om, hvordan religiøse spørgsmål skal fortolkes. De forskellige fortolkninger af, hvad undervisningen resulterer $i$, synes at være parallelle til en diskussion om, hvorvidt religiøse ritualer, som bliver simuleret i skolen $\mathrm{i}$ forbindelse med undervisningen, kan betragtes som værende lig med rigtige ritualer. I sin beskrivelse af en amerikansk retssag hvor forældre anklager en skolelærer for at ville omvende deres børn til muslimer, diskuterer antropologen Gregory Starrett forskellige forståelser af, hvorvidt det er udførelsen af ritualet i sig selv, der har en virkning, eller om det kræves, at de bagvedliggende intentioner og stemninger er religiøse, før ritualet er 'rigtigt' (Starrett 2009:229). Dette er tæt forbundet med en lignende overvejelse, nemlig hvorvidt det er den religiøse tro, der genererer ritualer, eller om ritualer også kan generere tro og derved potentielt omvende dem, der deltager i ritualet (ibid. 230, jf. Mahmood 2005). På samme måde synes Dannevangskolens forældres (og læreres) forskellige holdninger at være delt i forhold til, hvorvidt børn kan lære 'objektivt' om forskellige religioner uden at miste deres eget ståsted, eller hvorvidt undervisningsperspektivet nødvendigvis vil forme barnets tro.

For de yngre børns vedkommende blev ønsket om fritagelse jævnligt begrundet med en bekymring for, at børnene ville blive "forvirrede" hvis de skulle lære om kristendom samtidig med, at de skulle tilegne sig den grundlæggende viden om islam. Et eksempel på, hvordan den forvirring opleves, kommer fra faderen Kamal, som troede, at han havde fritaget sit barn fra kristendomskundskab, men ikke var bevidst om de nye regler om årlig fornyelse af fritagelse:

Kamal: Der skete en fejl med ham der. Fordi jeg har meldt ham ud fra kristendom. Og jeg vidste ikke, at man skal gøre det hvert år. I gamle dage skulle man melde ham ud fra kristendom én gang. Og så lige pludselig kommer han hjem og stiller sådan nogle spørgsmål, sådan nogle underlige spørgsmål til mig. Ja, han siger, at Jesus er Allahs søn, og jeg siger: "hvor har du lært det henne?!"

Da Kamal tilfældigt opdager, at sønnen Muhammad fortsat har kristendomskundskab, forsøger han at rette fejlen:

Jeg gik op på skolen for at snakke med dem og sagde, at han skal undtages fra kristendom. Og det... Og så bagefter var vi til 
forældresamtale, og så siger hun [læreren] "jamen, tosprogede børn vil have mere erfaring og få lært dansk" og på den måde, forstår du mig. Og så han bliver bedre, der er nogle begreber og ord, de findes i kristendom, han kan ikke osv. osv. Hun vil overbevise mig. Jeg sagde til hende: "jeg har ikke noget imod, at mit barn bliver bedre til dansk. Det har jeg ikke noget imod. Men den måde, du underviser ham, det er forkert". [...] Du ved, et barn på ni år eller otte år, når han tager to meninger, der krydser hinanden, så bliver han forvirret jo.

Det er tydeligt, at Kamal og sønnens lærer tillægger undervisningen i kristendomskundskab forskellige betydninger. Læreren henviser til fordelene ved sprogindlæring og evnen til at diskutere forskellige begreber. Som Katja også påpegede, handler kristendomskundskab her ikke meget om religion, men om at udvikle en evne til at begå sig i det danske samfund. For Kamal er det imidlertid undervisning i religion, og den vil præge sønnens tro. Det er værd at bemærke, at forældrenes logik om, at man lærer om sin egen religion, før man lærer om andre, er den samme logik, som kan findes bag folkeskolelovgivningens krav til faget kristendom: Først bliver børnene introduceret til kristendommen og senere til andre religioner.

Nogle vil måske spørge, hvorfor det er et problem, at Muhammad som 8-årig tror, at Jesus er Guds søn. Det er en misforståelse, og der er nok ikke nogen tvivl om, at han med tiden vil forstå, at der er forskel på, hvad muslimer og kristne tror i den henseende. Man kunne derfor tro, at Kamal frygtede, at læreren forkynder kristendommen eller prøver at omvende hans børn. Men da jeg spørger ham, om han tror, at læreren faktisk siger, at Jesus er Guds søn, eller om hun siger, at i kristendommen tror man, at Jesus er Guds søn, svarer han:

Det ved jeg ikke. Jeg tør ikke svare på det. Fordi jeg har ikke hørt det. Om hun siger, at i kristendommen bliver Jesus betragtet som Guds søn, eller om det er hendes egen mening, det ved jeg ikke. Jeg tør ikke sige det. Men barnet kommer hjem og ser det på den måde. Det er det.

Problemet er altså ikke lærerens intentioner, eller en frygt for, at læreren forkynder. Problemet er udgangspunktet, og det der bliver betragtet som resultatet. Som Kamal siger til læreren i det første citat: "Den måde, du underviser ham, det er forkert". En lignende holdning blev udtrykt af Said:

Det med kristendomskundskab. Allerede som kristne folk forklarer kristendom, det er forkert, det er i hvert fald vores synspunkt. Jeg vil hellere, hvis mit barn skal høre noget om kristendom, så skal han høre det fra mig.

Både Said og Kamal understreger, at det er helt fint, at børnene lærer om kristendommen, men de skal lære det fra et muslimsk perspektiv. Begge fædre henviser som eksempel til forskellene i den måde, hvorpå Gud 
bliver betragtet og talt om. Som Kamal siger, "du kan ikke forestille dig ham". Said har et mere konkret eksempel:

Gud eksisterede inden alting blev skabt, det er jøder, kristne og muslimer enige om. Og mine børn har lært, at Gud har skabt himlen. Gud eksisterede, inden himlen den blev skabt. Men kristne tænker Gud sidder i himlen. Hvordan kan de få det til det? Gud har skabt himlen og så bagefter sidder han inden $\mathrm{i}$ den eller hvad? Gud eksisterer uden himlen, uden sted og alt det der.

Hvor lærerne i vores interviews antog, at skolen kunne lære børnene om religioner generelt, ser disse forældres perspektiv anderledes ud. Ikke alle religioner er lige gode; der er et rigtigt og et forkert, og ens tro har konsekvenser for, hvordan man går til teologiske spørgsmål, fx hvorvidt Jesus er Guds søn eller ej. Her er kristendom ikke bare kulturarv, men en religion, der er forskellig fra deres egen. Nogle af de muslimske forældre, der lod deres børn deltage i kristendomskundskab, ville være uenige i den fortolkning. Efter deres mening kunne børnene sagtens lære om kristendom uden nødvendigvis at begynde at tro på det. Ligesom lærerne knyttede de læring om kristendom sammen med læring om det danske samfund:

Altså, de har alle tre været til kristendomsundervisning. De siger, at de ikke vil være med til det, men jeg siger, I skal gå, I skal lære det. Selvfølgelig har jeg også forklaret tingene, så kan I godt se kristen religion, fordi det er den danske kultur. Men vi er muslimer, så det kan I godt lære begge to på den måde, altså kultur og religion på den måde. (Ayse)

Disse grundlæggende fortolkningsforskelle gav sig også udtryk i forskellige holdninger til, om det kan betragtes som kristen praksis, hvis børnene overværer julegudstjenesten, synger salmer i musikundervisningen eller danser om juletræet i børnehaven. Er dette danske eller kristne traditioner, og hvilken betydning har det for deres eventuelle religiøse indhold, at de foregår i skolesammenhæng (jf. Anderson 2011:151)? Der eksisterede således meget forskellige opfattelser af, hvordan praksis i skolen skal fortolkes.

\section{Forhandlinger af privat, religiøs praksis}

Som vi har set ovenfor, deler skole, lærere og forældre altså en opfattelse af, at 'religion' er privat, men der findes forskellige opfattelser af, hvor bredt det skal fortolkes, og på hvilke måder religionens private dimension udspiller sig. Mens ovenstående diskussion primært relaterede sig specifikt til undervisningen i faget kristendomskundskab, vil jeg i det følgende se nærmere på andre tilfælde, hvor forældrene oplevede, at deres 'private religion' kom på spil i skolesammenhæng på en måde, så de følte, at grænsernes for familiens privatliv blev overtrådt. I den sammenhæng var 'respekt' (eller mangel på samme) en term, der gik igen, når forældrene omtalte, hvornår deres egne grænser blev overtrådt, eller hvornår en lærer overskred, hvad de anså som grænsen mellem familien og skolen. Her blev relationen til skolen til tider indskrevet i en bredere sammenhæng med muslimske familiers generelle position i det danske samfund. I citatet fra Kamal ovenfor er det fx tydeligt, at de reviderede 
regler om fritagelse fra kristendomskundskab, som skolelederen betragtede som en succes, fra nogle forældres perspektiv ikke var helt så vellykkede. En del forældre påpegede faktisk, at de anså regelændringen som mangel på respekt for deres religiøse overbevisning. Said, hvis barn også havde måttet tage et ekstra års kristendom, var en af dem, der udtalte sig mest kontant om de nye regler:

Du kan se, de er snu der i skolen. De tror vi er dumme, det er vi ikke. Før i tiden var reglen, du kan bare afmelde dit barn fra kristendom, så er det godkendt. Men så laver de det om, det er for nemt, sgu' da, at børnene bare kan afmeldes. Vi skal lige gøre det besværligt, og vi ved det jo godt, vi skal få de små børn til at deltage. [...] Og hvor står det henne, det der, da det kom som nyt, ikk? Det stod på et blad, det var ikke noget, der kom hjem til os. Det stod på et skoleblad, med småt skrift, og hvis du ikke er typen, der går og læser hele bladet, så ved du ikke nok.

Det er nok muligt, at skolen har forsøgt at informere forældrene på andre måder end via skolebladet, $\mathrm{fx}$ ved at annoncere ændringen på intranettet. Men faktum er, at mange forældre ikke kendte de nye regler, og de fortolkede som Said reglerne som et forsøg på at genere dem og gøre livet mere besværligt. Selvom de fleste forældre i øvrigt udtalte sig meget positivt om skolen og dens ledelse, indskrev de politikken for kristendomskundskab $\mathrm{i}$ en større ramme om politisk konflikt og diskrimination af muslimer i Danmark.

Relationen mellem skole og familie kom mere konkret i spil i forbindelse med nogle læreres kommentarer til nogle børns manglende deltagelse $\mathrm{i}$ alment udbredte traditioner, såsom fejringen af fødselsdag eller klippe/klistredag til jul. Både Said og hans kone nævnte fx, at en lærer havde kommenteret, at parrets 12-årige datter "var ked af det", fordi hun ikke fejrede sin fødselsdag og ikke fik nogle gaver til jul, udtalelser de af flere årsager var dybt uenige i. For det første er parrets børn vokset op uden at fejre fødselsdag, og det er således ikke noget, de sætter spørgsmålstegn ved. For det andet får børnene gaver på andre tidspunkter af året (fx ved fejringen af eid), og de lider dermed ikke materiel nød. Endelig - og det var måske det, der ophidsede Said mest gav læreren via sin kommentar indirekte udtryk for, at forældrene ikke havde føling med datterens tilstand eller manglede forståelse for hendes situation. Said følte tværtimod, at det var læreren, der kun så tingene fra sin egen side og fortsatte: "Fordi det er ens eget privatliv det her. Du kan ikke komme og fortælle mig, hvordan jeg skal leve mit liv herhjemme, og hvad vi vil og ikke vil".

I dette tilfælde ser vi et eksempel på, at en lærer fra forældrenes perspektiv tydeligt overskrider en grænse for, hvad skolen skal blande sig i. Hvis børnene skulle begynde at fejre deres egne fødselsdage, ville det præge hele familiens liv i en retning, forældrene ikke ønskede. Jeg har ikke talt med den pågældende lærer, men skal man fortolke det positivt, kan man formode, at hendes motivation lå $\mathrm{i}$ et ønske om at sikre børnenes sociale inklusion i klassen. Det mest interessante i dette eksempel er dog de utilsigtede konsekvenser af lærerens indblanding. Ligesom børnene ikke fejrede deres egen fødselsdag, var de kun 
undtagelsesvist med til andres. Et senere interview med parrets datter (som ikke var til stede ved ovenstående samtale) belyste hendes perspektiv på dette:

Marianne: Tænker du nogensinde over, at du ikke kan komme med til fødselsdage?

Zainab: Det, nej, ikke rigtigt. Jeg synes, det er fint nok, for vi hygger os meget godt herhjemme. Og fordi at det eneste, der er irriterende, er at der er rigtig mange, der siger, det er synd for mig. Rigtig mange fra klassen.

Marianne: Altså, dine klassekammerater?

Zainab: Ja, og det synes min lærer også, og jeg, jeg vil ikke have sådan, at de tænker, det er fordi mine forældre er onde, det vil jeg ikke have, at de skal tænke på den måde. Derfor siger jeg, I skal ikke dele invitationer ud til mig, fordi jeg kan ikke komme eller noget. Selvfølgelig nogle gange så vil jeg jo gerne, for så kan vi tage i svømmehallen og sådan. Men på den anden side så gider jeg heller ikke, for jeg holder, hvad vi skal tro på. Jeg bliver ikke ked af det eller noget. Næh, det gør jeg ikke.

Lærerens henvendelse medførte ikke en ændring i familiens praksis, men som citatet viser, er lærerens og kammeraternes holdning medvirkende til, at familiens 12-årige datter udviklede taktikker for, hvordan hun skal forholde sig, så de andre ikke tænker, at "mine forældre er onde". Disse taktikker indebærer at undgå at blive inviteret til fester og fødselsdage ved på forhånd at fortælle de andre elever, at hun alligevel ikke kan komme. Forhandlingen mellem skolen (her bredt forstået som både lærere og kammerater) og familien påvirker altså børnenes egen forståelse af deres position i det sociale rum.

Det er en vigtig pointe, at det ikke kun var de praktiserende muslimske forældre, der oplevede, at deres grænser for det private blev overtrådt i skolen. 9-årige Isabellas forældre fortalte fx om dengang, en sikkert velmenende lærer ved et skolearrangement fortalte deres datter, at hun ikke skulle spise den salami, der stod på buffeten, fordi det var svinekød. Hvad læreren ikke vidste, var, at netop i denne familie havde forældrene valgt, at børnene skulle spise svinekød, selvom de ikke selv gjorde:

Mona: Isabella kommer hjem, når de holder fest, ikke. Og så siger hun: "mor, min lærer har sagt til mig, du skal ikke spise fx pølser, fordi det er svinekød". Men jeg blev meget, meget ked af det, ikke. Fordi Isabella hun må gerne spise jeres svinekød. Hvorfor har læreren sagt, hun ikke skal spise svinekød, ja, direkte til hende?

Marianne: Hvad gjorde du så? Sagde du noget til læreren?

Mona: Nej, jeg har ikke sagt noget. Fordi jeg tænkte, at det ikke er deres skyld. Vi tænker generelt på muslimer, ikke, og så tror de, at det er Isabella også, at hun ikke må spise svinekød.

Ved at forvente at Isabella var muslim på en bestemt måde, satte læreren altså fokus på hendes religion på en måde, som forældrene ikke var enige 
i, og som overskred deres grænser for, hvad der er privat, og hvad læreren skal blande sig i. I den forstand kom familiernes muslimske baggrund nogle gange på spil i skolen på måder, som forældrene ikke havde forventet.

Eksemplet viser også, at familierne nogle gange skulle forholde sig til en idealtypisk opfattelse af, hvordan 'muslimer' gør. Dette gjaldt både forældre, der ved ansøgningen om at børnene skulle kunne bade for sig selv efter idræt, havde oplevet at blive mødt med en kommentar om, at "andre muslimske børn kan godt bade sammen med alle", og forældre, der sendte deres børn i skole, mens de fleste andre muslimske børn holdt fri til eid. I nogle tilfælde var dette en numerisk antagelse, ud fra hvad flertallet synes at gøre, og $\mathrm{i}$ andre tilfælde var det en antagelse om, hvad den rigtige muslimske praksis ville være. Derfor klagede Mona ovenfor heller ikke over lærerens handling, fordi hun vidste, at læreren havde nogle helt bestemte forventninger til muslimer generelt. Da Mona sendte sin datter i skole til eid, valgte hun da også at forklare hende: "vi er ikke rigtige muslimer".

Isabellas tilfælde er eksempel på, hvordan lærerne nogle gange blander sig i noget, som forældrene anser for deres ansvar, men det belyser også, hvordan konstruktionen af 'den muslimske elev' kan finde sted i skolen. Et andet eksempel på dette var, da 10-årige Ahmad i ramadanen blev spurgt af sin lærer, hvorfor han skulle faste, og hvor det stod henne i Koranen. For Ahmads forældre og ældre søskende var det utroligt provokerende, at læreren stillede en 10-årig dreng til ansvar for at forklare sin religion. Hassan, Ahmads 20-årige storebror, sagde:

Hvorfor skal læreren spørge sådan en lille dreng, når han ved, at drengen ikke kan svare på det? Det er kun for at sætte nogle spørgsmålstegn i drengens hoved. [...] Altså, jeg var meget tæt på bare selv at tage over på skolen og give læreren en skideballe. Man skal ikke stille sådan en lille dreng sådan nogle spørgsmål, det skal man bare ikke.

Recep, Ahmads far, påpegede også, at det er en "dum ide" at spørge en 10-årig om den slags ting, da han ikke selv har en chance for at fortolke kilderne eller for den sags skyld forstå arabisk nok til at læse Koranen, hadith eller andre bøger om islam. Selvom Ahmad er muslim, kan han som barn ikke forventes at have nok indblik $\mathrm{i}$ islam til at forklare eller forsvare specifikke handlinger. Som tidligere nævnt havde lærerne på skolen faktisk meget forskellige holdninger til, hvordan lærere skal forholde sig til elevernes religiøse baggrund. Ikke desto mindre illustrerer Ahmads tilfælde en trend, der er blevet påpeget af flere, nemlig at muslimske børn og unge afkræves en bevidsthed om deres religiøse identitet på en måde, som man aldrig ville forvente af en ung etnisk dansk kristen (fx Schmidt 2007: 23). Derved gives også betydning til de unges religiøsitet på en måde, som de ikke nødvendigvis selv er tilpas med. I mit materiale er det tydeligt, at børnenes fortolkning af spørgsmål om deres religion ændrer sig med deres alder. Mens de yngre børn generelt opfattede det som positivt eller et udtryk for interesse at blive spurgt om fx højtidstraditioner, havde der med alderen udviklet sig en decideret træthed over islam-relaterede spørgsmål. Nogle af de unge 
voksne sukkede over at blive spurgt om alle mulige ting, som de ikke havde nogen anelse om - fx kunne 26-årige Tariq med tyrkisk baggrund ikke forklare, hvorfor kvinder i Saudi-Arabien ikke må køre bil - mens andre klagede over, at ikke-muslimer ofte stiller et spørgsmål, fx om fasten, og så "bliver ved og ved og ved" med at spørge, selv når det første svar er blevet givet. Også de unge oplevede altså at skulle give indgående teologiske forklaringer på familiens religiøse praksis.

\section{Konklusion}

Denne artikel har vist, hvordan forhandlingen af 'privat' religiøs praksis finder sted mellem forældre og lærere på en dansk folkeskole. Nogle muslimske forældres forbehold over for, at deres børn deltager i religionsundervisningen, skal ikke forstås som en modstand mod, at børnene lærer om kristendom, men snarere som et ønske om at påvirke, hvordan og hvornår børnene lærer om den. Disse forældre har således en anden forståelse af, hvordan ansvaret for børnenes læring skal fordeles mellem skole og familie. Mens lærerne skelner mellem undervisning i religioner generelt og den private fortolkning af religionen, laver disse forældre ikke samme skel, men mener derimod, at religionsundervisning ikke kan foregå objektivt. Helt basalt synes konflikten også at omhandle, hvem der skal forme børnenes moral og grundlæggende værdier. På denne måde bør forhandlingerne om kristendomskundskab ikke kun fortolkes i et snævert perspektiv på kulturelle forskelle mellem 'muslimer' og 'danske værdier', men kan forstås som endnu en dimension af de forhandlinger mellem samfundsinstitutionerne familie og skole, der rækker langt tilbage i den danske historie.

Opfattelsen af, at religion tilhører privatsfæren, er udbredt $i$ en sekulær sammenhæng og deles af både lærere og forældre. Det er imidlertid værd at medtænke Dobbelaeres forståelse af skellet mellem offentlig og privat som et ideologisk skel (1999: 233). Når nogle forældre holder fast $\mathrm{i}$, at deres religiøse praksis er privat, synes det også at blive en måde at skabe plads til sin religion på uden at føle sig i konflikt med samfundet. At gøre det at være muslim til et privat anliggende bliver på denne vis en form for 'taktisk religion' (Woodhead 2013), der giver mulighed for at være religiøs i en sammenhæng, hvor et mere distanceret forhold til religiøsitet ellers tillægges værdi. De muslimske forældre, der talte mest om religionen som privat, var også dem, der insisterede mest på, at den skulle praktiseres og gøre en forskel i deres hverdag. Artiklens eksempler har belyst en række dimensioner af familiernes religiøse praksis, som de selv betragter som privat, men som alligevel til tider kommer i spil i mødet med skolen: Det gælder fx deres fortolkning af religion og deres fejring eller manglende fejring af specifikke traditioner. Ligeledes har børn og forældre oplevet at få gode råd om deres opførsel ud fra forventninger til, hvordan en muslim lever, eller de modtager spørgsmål om islam og religionens rolle i hverdagen. Noget tyder derfor på, at forskellige forståelser af det private er i spil, ligesom det tilknyttes forskellige sfærer. Både skole og forældre forstår hjemmets sfære som privat, men for forældrene vedbliver religiøs praksis også at være privat, selvom børnene færdes $i$ andre sfærer. Når religion anses som privat her, synes det at betyde, at det er en praksis, som andre ikke skal blande sig i, og som i øvrigt heller ikke vil påvirke andre $\mathrm{i}$ det offentlige rum. 
Ovenstående eksempler peger dog på, at fra skolens perspektiv er det personlige ikke længere privat, når det indgår i en skolesammenhæng. Som Sidsel Vive Jensen påpeger i sin artikel i dette tidsskrift, er skolens håndtering af religiøse praksisser ikke speciel. Tværtimod er skolens stærke autoritet et grundlæggende vilkår, som alle elever må forholde sig til i forskellige situationer. I den forstand udgør skolen et minisamfund, hvori eleverne skal integreres og forskellene imellem dem minimeres (se også Gilliams artikel).

På trods af dette synes familiernes mange forskellige måder at være muslimer på at være en kilde til evig forhandling - imellem skole og forældre, i forældregruppen eller imellem børnene. Derfor synes det oplagt, at færre antagelser om, hvordan den 'normale muslim' opfører sig, muligvis vil give rum til, at bredden af muslimske familiers praksis nemmere kan finde plads i skolen. Det er også vigtigt, at forældres forbehold over for kristendomskundskab ikke per automatik knyttes sammen med en modstand mod integration eller deltagelse i det danske samfund. Hvis religiøs tro betragtes som privat, er den ikke nødvendigvis i vejen for inklusion i samfundet generelt, selvom en religiøs tilgang til tilværelsen måske udgør et andet forhold til religion, end det der videregives i skolens civile enkulturation.

\section{Forfatterpræsentation}

Marianne Holm Pedersen er seniorforsker i Nationalsamlingsafdelingen (Dansk Folkemindesamling) på Det Kongelige Bibliotek. Med en baggrund som antropolog har hun i en årrække forsket $\mathrm{i}$ temaer relateret til hverdagsliv, tilhørsforhold og religiøsitet blandt muslimske flygtninge og indvandrere i Danmark. Hun er blandt andet forfatter til bogen Iraqi women in Denmark: Ritual performance and belonging in everyday life (Manchester University Press, 2014).

\section{Referencer}

Anderson, Sally, 2011: “Going through the motions of ritual. Exploring the 'as if quality of religious sociality of faith-based schools", i: Susan B. Ridgely (red.): The Study of Children in Religions. A Methods Handbook, New York University Press, New York.

Baumann, Gerd, 2004: "Introduction: Nation-state, schools and civil enculturation", i: Werner Schiffauer, Gerd Baumann, Riva Kastoryano og Steven Vertovec (red.): Civil Enculturation. Nation-State, Schools and Ethnic Differences in Four European Countries, Berghahn Books, Oxford.

Beckford, James A., 2003: Social Theory and Religion, Cambridge University Press, Cambridge.

Berglund, Jenny, 2013: "Swedish religion education: Objective but marinated in Lutheran Protestantism?”, i: Temenos 49 (2): 165-184.

Buchardt, Mette, 2008: “Identitetspolitik i klasserummet. 'Religion' og 'kultur' som viden og social klassifikation, studier i et praktiseret skolefag", ph.d. afhandling, Københavns Universitet. 
Dobbelaere, Karel, 1999: "Towards an integrated perspective of the processes related to the descriptive concept of secularization", i: Sociology of Religion 69(3): 229-247.

Gilliam, Laura, 2009: De umulige born og det ordentlige menneske. Identitet, ballade og muslimske fallesskaber blandt etniske minoritetsborn, Aarhus Universitetsforlag, Aarhus.

Gilliam, Laura og Eva Gulløv, 2012: Civiliserende institutioner. Om idealer og distinktioner i opdragelse, Aarhus Universitetsforlag, Aarhus.

Gitz-Johansen, Thomas, 2006: Den multikulturelle skole - integration og sortering, Roskilde Universitetsforlag, Roskilde.

Grillo, Ralph, 2004: "Islam and transnationalism", i: Journal of Ethnic and Migration Studies, 30(5): 861-878.

Gulløv, Eva, 2011: Welfare and self care: Institutionalized visions for a good life in Danish day-care centres, i: Anthropology in Action, 18 (3): 21-32.

Jenkins, Richard, 2011: Being Danish. Paradoxes of Identity in Everyday Life, Museum Tusculanums Forlag, København.

Jensen, Sidsel Vive, 2013: It Has Nothing to Do with Religion. Governance of Religious Practices in Danish Public Schools. Upubliceret ph.d. afhandling, Faculty of Arts, Aarhus Universitet.

Jensen, Sidsel Vive og Lene Kühle, 2013: "School Islam: An example of lived religion in the context of a secular public institution", i: Nathal M. Dessing, Nadia Jeldtoft, Jørgen S. Nielsen og Linda Woodhead (red.): Everyday Lived Islam in Europe, Ashgate, Farnham.

Jensen, Tina G., 2008: “To be 'Danish', becoming 'Muslim': Contestations of national identity?", i: Journal of Ethnic and Migration Studies, 34(3): 389-409.

Jepsen, Stine Irene A., 2012: 'Krislamister' og 'krislam'. En empirisk undersogelse af folkeskolefaget kristendomskundskab i multietniske klasserum, Upubliceret speciale, Faculty of Arts, Aarhus Universitet, Aarhus.

Mahmood, Saba, 2005: Politics of Piety. The Islamic Revival and the Feminist Subject, Princeton University Press, Princeton.

Nielsen, Jørgen S., 2011: "Setting the scene. Muslims in Denmark", i: Jørgen S. Nielsen (red.): Islam in Denmark. The Challenge of Diversity, Lexington Books, Lanham, Md.

Pedersen, Marianne Holm, 2014: "Islam in the family: The religious socialization of children in a Danish provincial town", i: Mark Sedgwick (red.): Making European Muslims. Religious Socialization among Young Muslims in Scandinavia and Western Europe, Routledge, London.

Rasmussen, Morten, 2004: "En skole i orkanens øje", i: Kristeligt Dagblad d. 23. oktober 2004.

Rubow, Cecilie, 2011: "Religion and integration. Three Danish models for the relationship between religion and society", i: Karen Fog Olwig og Karsten Pærregaard (red.): The Question of Integration: Immigration, Exclusion and the Danish Welfare State, Cambridge Scholars Publishing, Cambridge.

Schiffauer, Werner, Gerd Baumann, Riva Kastoryano og Steven Vertovec (red.): Civil Enculturation. Nation-State, Schools and Ethnic Differences in Four European Countries, Berghahn Books, Oxford. 
Schmidt, Garbi, 2007: Muslim i Danmark - muslim i verden. En analyse af muslimske ungdomsforeninger og muslimsk identitet $i$ arene op til Mubammadkrisen, Universitetstryckeriet, Uppsala.

Sedgwick, Mark, 2014: "Islam in Christianity: Religious education in the Danish folkeskole", i: Mark Sedgwick (red.): Making European Muslims. Religious Socialization Among Young Muslims in Scandinavia and Western Europe, Routledge, London.

Starrett, Gregory, 2009: Islam and the politics of enchantment, i: Journal of the Royal Anthropological Institute (N.S.): 222-240.

Woodhead, Linda, 2013: "Tactical and strategic religion", i: Nathal M. Dessing, Nadia Jeldtoft, Jørgen S. Nielsen og Linda Woodhead (red.): Everyday Lived Islam in Europe, Ashgate, Farnham. 